\title{
ERBB2 Gene Amplification
}

National Cancer Institute

\section{Source}

National Cancer Institute. ERBB2 Gene Amplification. NCI Thesaurus. Code C36638.

A molecular genetic abnormality indicating the presence of multiple copies of the ERBB2 gene. 